\title{
Review
}

International Archives of
Allergy
Immunology

\section{Years in Review: Recent Progress in Cellular Allergology}

\author{
Bernhard Kratzer Winfried F. Pickl \\ Institute of Immunology, Center for Pathophysiology, Infectiology and Immunology, \\ Medical University of Vienna, Vienna, Austria
}

\section{Key Words}

Allergy - T cells - Th17 cells $\cdot$ Regulatory T cells .

Dendritic cells · Monocytes - Mast cells · Basophils .

Eosinophils · Asthma

\begin{abstract}
This review highlights the recent key advances in the biology of CD4 ${ }^{+}$effector T cells, antigen-presenting cells, Th17 and T regulatory cells, as well as immediate effector cells, such as mast cells, basophils and eosinophils, which are critically contributing to the better understanding of the pathophysiology of allergic diseases and are helping to improve their diagnosis and therapy. Some of the key advances with a direct impact on allergic asthma research and treatment are summarized.

(c) 2016 The Author(s)

Published by S. Karger AG, Basel
\end{abstract}

\section{CD4 $^{+} \mathbf{T}$ Helper Cells}

$\mathrm{CD}^{+} \mathrm{T}$ cells are important to combat microbial pathogens, however, different types of pathogens require different responses. Therefore, different forms of $\mathrm{CD} 4^{+}$effector cells are required, which are characterized by the expression of specific surface molecules and the secretion of a specific set of distinct cytokines, and due to differen-

\section{KARGER}

E-Mail karger@karger.com www.karger.com/iaa

\section{(c) 2016 The Author(s) \\ Published by S. Karger AG, Basel 1018-2438/16/1691-0001\$39.50/0}

This article is licensed under the Creative Commons AttributionNonCommercial-NoDerivatives 4.0 International License (CC BYNC-ND) (http://www.karger.com/Services/OpenAccessLicense). Usage and distribution for commercial purposes as well as any distribution of modified material requires written permission. tial chemokine receptor expression have the capacity to enter into specific organs or organ systems [1]. These features are indispensable for the activation of other cell types, such as lymphocytes, macrophages and dendritic cells. Consequently, the role of $\mathrm{CD} 4^{+} \mathrm{T}$ cells is largely indirect, which gave them the name 'helper' cells [2]. Differentially polarized $\mathrm{CD} 4^{+} \mathrm{T}$ helper (Th) cells might also be involved in the decision of whether the immune response to an innocuous antigen, e.g. an allergen, either leads to sensitization or protection $[3,4]$.

In an attempt to impact on the effector functions and/ or polarization of Th cells, Verheijden et al. [5] investigated the effects of galacto-oligosaccharides (GOS) on the production of the alarmin IL-33. IL-33 plays an important role in mucosal barrier tissues by impacting on Th2 cell function via the ST2 receptor [6]. GOS represent nondigestible oligosaccharides and are currently added to infant milk formulas with the aim of modifying the intestinal microbiome. Of note, dietary GOS application significantly reduced deoxynivalenol-induced IL-33 expression in the distal small intestine, which was paralleled by reduced ST 2 expression on Th2 cells. Similarly, dietary supplementation with GOS reduced IL-33 and ST2 expression levels in the lungs and bronchoalveolar lavage fluids of house dust mite-allergic mice. Whether the biological effects of GOS supplementation result from alterations in the microbiome, the GOS-mediated protection

Correspondence to: Prof. Winfried F. Pickl

Institute of Immunology, Center for Pathophysiology, Infectiology and Immunology Medical University of Vienna

Lazzarettgasse 19, AT-1090 Vienna (Austria)

E-Mail winfried.pickl@meduniwien.ac.at 
of the intestinal barrier function - by maintaining the integrity of tight junctions - or direct interaction of GOS with epithelial and immune cells remains to be shown. Nevertheless, these data clearly show that the detrimental effects of disturbed barrier function can be counteracted by dietary GOS supplementation and that a reduction of IL-33 levels seems to be critically involved in this protective effect. A more direct approach was taken by Holvoet et al. [7] who cocultured human T cells, skewed towards the Th2 phenotype by a classic protocol in a 3-day culture with IL-4 and anti-CD40 mAbs [8], with a collection of 35 different probiotic bacterial strains and analyzed the secretion levels of signature cytokines. Of note, all strains downregulated IL-5 secretion levels similarly to or even stronger than LPS, which was used as a control. In contrast, IL-4 and anti-CD40 treatment rendered Th2skewed cells more susceptible to IFN- $\gamma$ production upon the addition of probiotics. The situation was different for IL-10 secretion. In fact, all probiotics induced IL-10 secretion, although to a much higher degree when cells were not prestimulated with IL-4 and anti-CD40 mAbs. The studies performed with cells obtained from healthy volunteers polarized towards the Th2 phenotype could be largely recapitulated with cells obtained from grass pollen-allergic individuals and ovalbumin (OVA)-specific murine splenocytes. Notably, the immunomodulatory effects of some probiotics stood out, such as that of Lactococcus lactis, which turned out to be a strong inducer of both IFN- $\gamma$ and IL-10 secretion, and that of the Escherichia coli strains under investigation, which were identified as effective inducers of IFN- $\gamma$. The main finding was a certain degree of strain specificity in their immunomodulatory potency and differences in their potency to counterbalance established Th2 reaction profiles. Besides simply modulating cytokine profiles, it cannot be excluded that probiotics might also be involved in the reinforcement of the intestinal barrier, which would, however, require alternative tests for accurate evaluation. Nevertheless, the established in vitro assay allows the preselection of probiotics revealing a potentially beneficial cytokine pattern as candidates for detailed in vivo evaluations in the future [7].

The systemic and coordinated movement of lymphocytes in the body strongly depends on chemokine-based gradients induced by tissue- or cell-specific chemokine secretion and reciprocal chemokine receptor expression on the responding cell populations for efficient cell targeting [9]. Properly targeted lymphocytes are then prone to tissue-specific functions and also pathology, and these important immunoregulatory aspects have been studied by several groups. Barbarroja-Escudero et al. [10] analyzed peripheral blood $\mathrm{T}$ cells of patients with nonallergic asthma with respect to their chemokine receptor expression levels and related their findings to the dosage of fluticasone propionate (FP) medication applied. In high-dose FP-treated patients, $\mathrm{CD}^{+} \mathrm{T}$ cell numbers and percentages were found to be significantly reduced. Of note, untreated patients revealed a significant increase in both CCR6 and CXCR 3 expression on $\mathrm{CD} 8^{+} \mathrm{CD} 25^{+} \mathrm{T}$ cells, including CD25 $5^{\text {high }} \mathrm{T}$ cells, which seems to become normalized upon FP treatment, irrespective of the dosage applied. The chemokine receptors CCR2, CCR5 and CXCR4 did not show between-group differences. The fact that CCR6 is overexpressed in untreated asthma patients seems to be especially interesting, since CCR6 has been shown to target lymphocytes to the lungs, and might thus be a sign for poorly controlled asthma. The situation is more complex once patients are under medication since changes in receptor densities might be related to the systemic effects of FP treatment; however, they might also be related and mirror the severity of disease, since patients with severer forms of asthma are also more likely to receive standard- or even high-dose medication. Taking these confounders into account it was nevertheless interesting to observe increased CCR5 expression on several $\mathrm{CD}^{+}$and $\mathrm{CD} 8^{+} \mathrm{T}$ cell subsets derived from patients receiving standard-dose FP relative to those of healthy controls. Patients treated with high-dose FP revealed a significant reduction in CCR2 expression levels. CCR2 ${ }^{+} \mathrm{T}$ cells are known to be involved in the pathogenesis of severe asthma [11] indicating that either the effector memory pool becomes reduced or CCR2 ${ }^{+}$effector memory cells are confined to other compartments within the body. Thus, drug-induced changes in the chemokine receptor expression pattern might facilitate a better understanding of organ pathology and their amelioration in asthma [10].

Besides the respiratory tract, the skin and the eyes (conjunctiva) certainly belong to major target organs of hypersensitivity reactions [12]. It is therefore of special interest to better understand both the chemokine-receptor makeup and the effector cell potential of skin- and conjunctiva-homing lymphocytes. Skin-homing Th cells expressing the chemokine receptors CCR4, CCR6 and CCR10 preferentially produce IL-22 but not IL-17, which gave them the name Th22 cells $[13,14]$. Such cells are enriched in the skin of atopic dermatitis (AD) patients. Since lesional skin in $\mathrm{AD}$ is known to be heavily colonized by Staphylococcus spp., Niebuhr et al. [15] were interested in whether staphylococcal enterotoxin B (SEB) and a-toxin would directly stimulate human Th cells for IL-22 
production. In fact, SEB and $\alpha$-toxin led to the enhanced secretion of IL- 22 from Th 22 cells, generated by coculture in IL-6- and TNF- $\alpha$-containing medium, but also from memory T cells. Of note, T cells derived from AD or psoriasis patients or healthy controls secreted similar amounts of IL-22 when exposed to SEB or a-toxin. This indicates that skin-homing memory $\mathrm{T}$ cells might become hyperstimulated by staphylococcal antigens once they have reached lesional skin colonized with large numbers of staphylococci, which in fact might critically contribute to the amplification of inflammation. In a related publication the function of skin-homing lymphocytes was studied by investigating individuals suffering from papular urticaria induced by flea bites. Of note, patients with papular urticaria presented with significantly more flea antigen-specific CLA $4^{+}$skin-homing T cells secreting IFN- $\gamma$, IL-4, IL-10 and IL-17 when compared to healthy controls. Interestingly, after more than 5 years of disease duration, skin-homing CLA $4^{+} \mathrm{T}$ cells lost their capacity to produce IL-4, while they largely maintained their IL-10 and IL-17 secretion capacity. Compatible with this hypothesis, the frequency of IFN- $\gamma$-positive T cells was reduced in both skin-homing and non-skin-homing lymphocytes in such patients [16].

Since chemokines and their receptors are not only responsible for lymphocyte trafficking but also contribute to the fine architecture of secondary lymphoid organs $[17,18]$, Shoji et al. [19] were interested in delineating the contribution of chemokines/chemokine receptors to the formation of inducible conjunctiva-associated lymphoid tissue (iCALT). The formation of iCALT was most efficiently induced by a combination of percutaneous and ophthalmic sensitization, revealing a significant accumulation of inflammatory cells including eosinophils and lymphocytes in sub-conjunctival tissues, which was accompanied by follicular lymphoid hyperplasia, including the accumulation of $\mathrm{CD} 20^{+} \mathrm{B}$ cells. Lymphoid follicles revealed an elevated expression of Th2 chemokines and corresponding chemokine receptors, including CCL17, CCL22 and CCR4, which were significantly higher in the keratoconjunctivitis than in the $\mathrm{AD}$ and healthy control group. PCR array-based evaluation of marker expression revealed marked overexpression of several chemokines and their respective receptors, including CCL20/CCR6, CCL17/CCR4 and CCL5/CCR3. The establishment of a reliable model for the induction of ophthalmic hypersensitivity along with the identification of associated chemokines and their receptors involved in that process not only contributes to the better definition of the pathology of such lesions, but also provides a collection of potentially helpful biomarkers for monitoring treatment-related changes in local pathology in this important target organ.

So far, allergen-specific immunotherapy (subcutaneous or sublingual) represents the only causal treatment of IgE-associated hypersensitivity reactions [20]. Biological model systems allowing the detailed investigation of hyposensibilization schedules including dose-response estimations and accurate monitoring of the respective immediate and long-term responses are therefore of utmost importance [21]. Along those lines van Rijt et al. [22] established a birch pollen-specific animal model by sequentially immunizing BALB/c mice with birch pollen extract, which led to airway hyperresponsiveness accompanied with hallmarks of allergic inflammation, such as bronchoalveolar lavage fluid eosinophilia and IL-5 hyperproduction, increased allergen-specific serum IgE levels as well as increased IL- 4 and IFN- $\gamma$ production by lungdraining lymph node cells upon restimulation. Subcutaneous immunotherapy led to a dose-dependent early decrease in Th2 cytokines, however, lung function was only ameliorated at later time points when allergen-specific IgG2a levels further increased. This study indicates that suppression of Th2 cytokines along with diminished eosinophil recruitment might not be sufficient to reduce airway hyperreactivity. Instead, amelioration of airway hyperreactivity might require a certain length of time in order to build up sufficiently high allergen-specific IgG2a titers. Of note, IgE levels increased until the sixth subcutaneous injection and then plateaued while IgG2a levels further increased, which led to gradually decreased IgE/ IgG2a ratios from the seventh dose onwards. The authors have established a valuable model for studying the finetuning of allergen-specific immunotherapy for a highly human-relevant allergen.

\section{Th17 Cells}

Th17 cells represent a newly identified Th cell subset $[23,24]$ characterized by the surface expression of CD161 [25] and the production of IL-17A, IL-17F, IL-21 and IL22 . Since IL-17 promotes GM-CSF production, its secretion also indirectly supports neutrophil generation [26]. Moreover, IL-17 promotes neutrophil recruitment to the site of inflammation by the induction of chemokine synthesis [26]. Neutrophils represent an important defense mechanism against extracellular microorganisms, such as bacteria and fungi, making Th 17 cells an extremely important player during the defense of infections caused by pathogens such as Staphylococcus aureus, Klebsiella pneu- 
moniae and Candida albicans [27, 28]. Besides this, Th17 cells play an important role in the pathogenesis of autoimmune and autoinflammatory diseases, including allergies $[29,30]$. The study by Qin et al. [31] identified respiratory syncytial virus (RSV) infection of human bronchial epithelial cells as a major driver of leptin oversecretion, which in turn promoted Th17 and concomitantly suppressed Th2 subset differentiation, possibly induced by the regulation of Erk 1/2 phosphorylation. It has been shown previously that supernatants from RSV-infected human bronchial epithelial cells significantly increased both the differentiation of Th17 and Th2 subsets and decreased the differentiation of $\mathrm{T}$ regulatory (Treg) subsets. However, the molecules responsible for that process remained elusive. The authors have attained preliminary results from microarray screening experiments showing a significant elevation of leptin mRNA levels in RSVinfected human bronchial epithelial cells, which could be confirmed on the protein level in this publication. These are important findings since increased levels of Th17 subsets apart from Th2 subsets have been widely observed in asthma. Identification of leptin as a major driver of the escalation cycle leading to full-blown disease might open new and interesting avenues for potential therapeutic interference [32].

Along these lines, Naji et al. [33] compared circulating Th17 cell numbers and IL-17 levels produced by isolated peripheral blood mononuclear cells (PBMCs) of human atopic asthmatics before and after allergen inhalation challenge as well as atopic nonasthmatics and normal controls. They found a significant increase in circulating Th17 cells in asthmatics when compared to normal subjects. Moreover, PBMCs of atopic asthmatics produced significantly more IL-17 in vitro, mostly IL-17A, when compared to PBMCs derived from healthy controls. These results confirm earlier studies performed in murine models of allergen-induced airway disease and represent further proof of the importance of Th17 cells for the pathogenesis of allergic diseases and establish peripheral blood Th17 cell counts as an attractive monitoring tool for asthma. Very much in line with the previous study, Wang et al. [11] were interested in clarifying the molecular mechanisms guiding Th17 cells to the lungs in severe asthma. Therefore, the authors studied the effects of anti-CCL2 antibodies and CCR2 antagonist on the induction of allergic asthma, the levels of IL-17 and the frequencies of CCL2 ${ }^{+}$Th17 and Tc17 cells, as well as lung inflammation. Of note, blocking the CCL2/CCR2 axis significantly reduced recruitment of Th17 cells but not of Tc17 cells to the lungs, and also suppressed airway in- flammation. This indicated that the CCL2/CCR2 axis orchestrates the recruitment of Th17 cells to the lungs, which, in turn, could be an attractive target for clinical exploration in the future.

While a number of disease states are caused or accompanied by an increase in Th17 cell numbers, recent evidence suggests that others, such as urticaria or food allergy, might in fact be inversely correlated with Th17 cell numbers. In support of this notion, Dhuban et al. [34] found significantly lower IL-17 production by Th17 T cells derived from the peripheral blood of food-allergic individuals when compared to PBMCs of healthy controls. For that purpose, PBMCs were cultured with peanut allergen Ara h 1 or 2, gliadin or tetanus toxoid for 9 days. Besides the reduction of IL-17-producing cells, a significantly lower percentage of $\mathrm{CD}^{+}{ }^{+} \mathrm{FoxP} 3^{+}$Treg was evident, suggestive of a concomitant reduction of the Treg compartment in children with food allergies. The authors propose that defects in IL-17 production and the resulting immune deviation might, in fact, predispose affected individuals to food allergies. Nevertheless, the critical contribution of defects in the generation and homeostasis of FoxP3 ${ }^{+}$Treg cells impacting on the sensitization to distinct foods cannot be excluded at present.

\section{Treg Cells}

Different subsets of naturally occurring Treg cells have been defined and reviewed recently [35]. They express the coreceptor CD4, high levels of the high-affinity IL-2 receptor, CD25, and are positive for the transcription factor FoxP3 [36]. Treg cells are assumed to display a protective role in the immune response against allergens, with functional Treg deficiency being significantly associated with an increased risk for developing allergic diseases [37]. Tregs seem to play a crucial role during specific immunotherapy, especially in the early stages, where they apparently modulate the immune response by release of their suppressive cytokines TGF- $\beta$ and IL-10 [38-40]. However, as it is now understood, the levels of $\mathrm{CD} 4{ }^{+} \mathrm{CD} 25^{+} \mathrm{FoxP}^{+} \mathrm{CD} 127^{-}$Treg cells already inversely correlate with allergen-specific serum IgE levels in allergic children [41]. In fact, Treg levels were especially low in patients with symptoms of $\mathrm{AD}$ and/or food allergy. The clear-cut results obtained by the authors might have to do with the fact that CD127 negativity besides FoxP3 positivity was used to unequivocally identify the Treg population, making the sometimes difficult task of discriminating between bona fide Treg cells and recently activated $\mathrm{T}$ 
effector cells easier and providing another example for a possible link between allergy and defective immunoregulation.

Since a complete lack but also incomplete deficiency of Tregs might predispose to allergic diseases [42], several studies evaluated protocols to potentially increase Treg numbers in vivo in the past [43]. Such strategies might be helpful for the development of a functional vaccine or be suitable as an adjuvant strategy for the treatment of allergic diseases [44]. Along these lines, $\mathrm{Wu}$ et al. [45] studied the effects of systemic treatment with 5-azacytidine in an OVA-based murine model of airway hyperreactivity. Of note, 5-azacytidine dose-dependently ameliorated airway hyperreactivity, as determined by enhanced pause measurement, decreased eosinophil infiltration of the lungs, lowered OVA-specific IgG1 and IgE serum levels, and decreased production of Th2 cytokines by splenocytes derived from drug-treated mice in a dose-dependent manner. A total of 9 doses of 5-azacytidine were applied twice weekly during OVA sensitization. This ensured drug interference with ongoing sensitization ultimately leading to the establishment of full-blown allergic disease. Further experiments depleting Tregs by the use of anti-CD25 antibodies completely reversed the beneficial phenotype, demonstrating the dependency of alleviation of airway inflammation from the induction of increased Treg numbers.

A different strategy to increase Treg numbers was explored by Yoshida and colleagues [46] by applying Lactobacillus plantarum to experimental animals via the oral route. It had been shown previously that the feeding of mice with $L$. plantarum is associated with higher Treg numbers in spleens and Payers patches and lower levels of serum IgE, however, the mechanism for this regulation has remained unclear so far. In their follow-up study, Tregs induced with the bacteria were adoptively transferred into mice sensitized to $\beta$-lactoglobulin. This maneuver decreased serum IgE levels and inhibited allergic skin reactions indicating that Treg cells not only influence systemic IgE levels, but might also interfere with mast cell degranulation [47]. Mechanistically, the biological effects induced by L. plantarum might be accomplished by Treg-based suppression of long-lived plasma cells [48] and/or OX40/OX40L-based inhibition of mast cell degranulation [49].

In contrast to the generally beneficial effects of Tregs during the physiological immune response against usually innocuous antigens such as allergens, the overabundance of such cells might, however, significantly interfere with diagnostic procedures aimed at identifying patients with (drug) hypersensitivity reactions. Consequently, positive results in in vitro lymphocyte transformation tests (LTT) might become masked by the presence of Treg cells deteriorating test sensitivity. Therefore, Srinoulprasert and Pichler [50] compared standard LTT with Treg-depleted LTT. Significantly, Treg depletion increased the LTT sensitivity to over $80 \%$ while maintaining test specificity. Of note, the Treg depletion methods applied, i.e. flow cytometric or immunomagnetic bead based, did not influence the beneficial outcomes.

\section{Monocytes and Dendritic Cells}

Dendritic cells are the most important antigen-presenting cells, which capture the antigen in the periphery, traffic to their tissue-draining lymph nodes and process and present the captured antigens (allergens) to T lymphocytes through MHC-T cell receptor interactions [51]. Dendritic cells can respond to exogenous stimuli by upregulating costimulatory but also coinhibitory molecules (e.g. CD80, CD86 and OX40L) and cytokine secretion (e.g. IL-10 and IL-12), which critically divert the subsequent immune response into different directions [52]. In the initial years after their discovery, experimental procedures associated with the exploration of dendritic cell biology were quite laborious and cumbersome. The field of dendritic cell research was, however, revolutionized by the finding that highly purified peripheral blood monocytes can be differentiated towards dendritic-like cells $[53,54]$. From that point on a number of studies focused on the function of antigen-presenting cells and their role during the polarization process in allergic diseases [55].

Along those lines, Ashjaei et al. [56] were interested in delineating the contribution of autologous dendritic cells to Th cell polarization. While coincubation of monocytederived dendritic cells (mdDC) obtained from polysensitized individuals with sensitizing allergens (Bet $\mathrm{v} 1$ or Phl p 5) did not change their surface marker expression profiles, when compared to mdDC of healthy controls, such allergen-pulsed mdDC significantly drove Th2 cytokine production by autologous T cells. The authors found that this effect was in accordance with the sensitization profile of the patients under investigation, which was not observed when mdDC were pulsed with an unrelated allergen. Besides Bet v 1, the authors could show that Phl p 5 is also able to elicit Th2-type T cell responses in polysensitized individuals, while leaving the levels of IL- 10 secretion unchanged. This either points to special features of the sensitizing allergens, which become imprinted onto 
the involved dendritic cells, as discussed and entertained by the authors, or rather mirrors already elevated allergen-specific $\mathrm{T}$ effector cell levels present in such specifically sensitized individuals. These findings, together with the observation of Dong et al. [57] that rapamycin-treated immature dendritic cells lead to the induction of Treg cells, add additional support to the concept that dendritic cells critically shape the T cellular immune response. Antigen-presenting cells receive important cues, such as 'danger signals', by specifically sensing their environment with their specific set of surface receptors, including histamine receptors [58]. The detailed study of the expression and function of histamine receptors on dendritic cells has the potential to shed important light onto the putative interplay between mast cell activation and the function of antigen-presenting cells [59]. Glatzer et al. [60] measured the expression of the different histamine receptors on monocytes and myeloid dendritic cells. They clearly demonstrated expression of histamine receptors 1 , 2 and 4 (slightly higher on dendritic cells compared to monocytes) while histamine receptor 3 was consistently absent. Stimulation of myeloid dendritic cells with poly $\mathrm{I}: \mathrm{C}$ in the presence of different doses of histamine led to the upregulation of CXCL1 and downregulation of TNF- $\alpha$, CCL1, IL-6 and IP-10. In histamine-receptor blocking assays applying monoclonal antibodies, the authors could convincingly show that signaling via histamine receptor 2 and 4 on monocytes and myeloid dendritic cells is responsible for IP-10 downregulation. Reduced IP-10 expression might, in fact, promote Th2 polarization of $\mathrm{T}$ cells due to the absence of Th1 cytokines. In a similar effort, Lee et al. [61] were able to prove the functional importance of histamine receptor 1 in murine bone marrow-derived dendritic cells. During the maturation of dendritic cells, the presence of the histamine receptor 1 antagonists ketotifen and cyproheptadine led to a significant downregulation of TNF- $\alpha$ and IL-6 secretion, an effect not observed when the other two receptors ( 2 and 4 ) were blocked. However, histamine receptor 1 blockade did not alter the expression of the dendritic cell maturation marker molecules CD80, CD86, MHC class II, CD40 and CD11c, or the T cell stimulatory capacity of dendritic cells. The observed changes were attributable to alterations induced in the NF- $\kappa B$ signaling pathway involving c-Rel. In fact, with an adoptive transfer model of OVA airway hyperreactivity, the authors demonstrated that bone marrow-derived dendritic cells treated with ketotifen were able to prevent airway eosinophilia and Th2 cytokine expression when compared to vehicle-treated cells.
While dendritic cells are certainly the major antigenpresenting cells in our bodies, monocytes also carry out important antigen-presenting tasks and thereby either contribute to immunity or - in the case of hypersensitivity reactions - disease [62]. Monocyte subsets can be characterized by their differential CD14 and CD16 expression levels [63]. The 'classical' monocytes are strongly positive for CD14 and negative for CD16 $\left(\mathrm{CD} 14^{++}\right.$ CD16- monocytes) and constitute the majority of all monocytes in healthy individuals. In contrast, monocytes positive for CD16 account for only $5-15 \%$ of all monocytes, but their frequency increases significantly in inflammatory conditions such as sepsis, tuberculosis and atherosclerosis. The upregulation of CD16 and the CD14 expression levels are used to discriminate between intermediate monocytes $\left(\mathrm{CD} 14^{++} \mathrm{CD} 16^{+}\right)$and so-called nonclassical monocytes $\left(\mathrm{CD} 14^{+} \mathrm{CD} 16^{++}\right)$[64]. Moniuszko et al. [65] investigated whether the phenotypes of different monocytes and $\mathrm{CD} 4^{+} \mathrm{T}$ cells in the peripheral blood of allergic patients suffering from house dust mite-sensitive allergic rhinitis differ from those of healthy controls, and whether changes in monocyte subsets and $\mathrm{T}$ cells would be interdependent. In contrast to the study of Ashjaei et al. [56], the authors found that in allergic individuals the phenotype of circulating monocytes is significantly different from that seen in healthy individuals. In fact, the upregulation of the monocyte mannose receptor CD206 and the IL-10R and concomitant downregulation of the IL-4R highlights the intensive cross-talk between innate and adaptive immune cells during allergen-specific immune responses in patients. Moreover, the $\mathrm{CD} 16^{+}$monocyte subsets, i.e. the $\mathrm{CD} 14^{++} \mathrm{CD} 16^{+}$intermediate and the nonclassical $\mathrm{CD} 14^{+} \mathrm{CD} 16^{++}$monocytes, were significantly enriched in patients, pointing to allergen-specific alterations within the compartment of antigen-presenting cells in allergic patients. These alterations were associated with significantly decreased frequencies of $\mathrm{CD} 4^{+} \mathrm{CD} 25^{\text {high }} \mathrm{T}$ cells in allergic patients as compared to healthy controls. Since previous reports have already shown that the $\mathrm{CD} 14^{+} \mathrm{CD} 16^{++}$and, to a lesser extent, the $\mathrm{CD} 14^{++} \mathrm{CD} 16^{+}$monocyte subset play critical roles in asthmatic patients, protocols for their improved depletion were intensively sought for. In that context, it was shown that short-term glucocorticoid treatment efficiently depletes monocyte subsets. In an effort to reduce the potentially harmful glucocorticoid doses required, Grubczak et al. [66] combined glucocorticoid treatment with 1- $\alpha$, 25-dihydroxyvitamin $\mathrm{D}_{3}$ treatment and observed synergistic effects with regard to monocyte subset depletion. Notably, in the presence of 1- $\alpha, 25$-dihy- 
droxyvitamin $\mathrm{D}_{3}$ much lower doses of glucocorticoids were required to achieve a similar degree of monocyte subset depletion as compared to glucocorticoid treatment alone, opening the door for attractive new treatment modalities.

\section{Mast Cells}

Mast cells are typical sentinel cells within tissues, such as skin, the intestinal and airway mucosa, as well as the conjunctiva, which form immediate contacts with the external environment $[67,68]$. Mast cells express the highaffinity IgE receptor, can become sensitized with allergen-specific IgE and, after crosslinking upon allergen encounter, release potent mediators, including histamine, leukotrienes, tryptase and others, and are responsible for the multitude of local and systemic reactions observed in IgE-associated hypersensitivity reactions [69]. Mast cell lines have been a valuable tool to study the biology of mast cells in the past. Since 2003 three major mast cell lines have been widely used for research purposes - HMC-1 (human mast cell leukemia-1) [70], LAD2 (laboratory of allergic diseases 2) [71] and LUVA (laboratory of University of Virginia) [72]. It turned out that the LAD2 cell line most closely resembles human primary mast cells, is genetically stable and has a constant doubling time if handled according to the original instructions. However, the degranulation capacity of LAD2 may deteriorate when cells are kept in culture for prolonged periods of time. Accordingly, the authors recommend switching to frozen stocks of early passages of LAD2 once a year [73]. One of the hallmarks of the detrimental tissue remodeling process in asthma is represented by a dramatic increase in the smooth muscle cell mass around the bronchial tree. In order to investigate whether or not smooth muscle cells become influenced by mast cells, the above-described HMC-1 cell line served as a model. Coculture experiments using conditioned medium of FceR- $\alpha$ chain-transfected HMC- 1 cells induced upregulation of IL- 6 and IL-8 secretion in smooth muscle cells, which was even more pronounced if the mast cells were activated, e.g. by sensitization with IgE followed by stimulation with antigen. Furthermore, it was shown that the responsible factor(s) in conditioned medium of HMC-1 cells and acting on smooth muscle cells were most likely proteinaceous and delivered their activity by induction of the MAPK pathway [74]. These findings are paradigmatic for the important interactions between tissue-resident mast cells and their 'contractile' surroundings.

Years in Review: Cellular Allergology
In order to reach and accumulate in target tissues, mast cells are endowed with important tissue migratory functions $[75,76]$. An important facilitator in that respect is MMP-2 (matrix-metalloprotease 2). By studying RBL$2 \mathrm{H} 3$ and bone marrow-derived mast cells, Noma et al. [77] provided evidence that the NF- $\mathrm{KB}$ inhibitor (-)-DHMEQ reduces MMP-2 expression and, thus, decreases cellular invasion similar to the MMP inhibitor GM6001. This identified NF- $\mathrm{\kappa B}$ as a potential target to reduce inflammation-induced mast cell invasion and accumulation.

Mast cell granules are also a rich source for proteases, among them also granzyme B, ready for release upon activation [67]. Recently, Rönnberg et al. [78] discovered that mast cells also express granzyme $\mathrm{H}$, which has similar proteolytic activity as granzyme D. Granzyme $\mathrm{H}$ was initially described in T and NK cells, but its exact function in mast cells is elusive and remains to be shown.

Morphologically, mast cells are not always easy to quantify in clinical samples since special histologic treatment is required for their unequivocal identification. Therefore, Hagel et al. [79] resorted to quantifying tissue tryptase levels in endoscopically obtained colorectal samples of foodallergic individuals. Significantly, individuals with a manifest food allergy presented with clearly elevated tissuetryptase levels when compared to healthy controls or food-allergic patients in remission. Thus, intestinal tissue tryptase levels in endoscopically removed samples might help to objectively confirm the diagnosis of a manifest food allergy and its remission. On a similar note, local expansion of mast cells, comparable to systemic mastocytosis, might be associated with an increased propensity for anaphylactic reactions. In that context, a very interesting case report described a patient who presented with a clonal mast cell activation syndrome upon ingestion of sulfites, which are frequently used as antioxidative food preservatives and are also present in many wines. No specific $\operatorname{IgE}$ elevation could be identified in this patient, thus it was speculated that mediator release from mast cells is the consequence of a hitherto unknown mechanism [80].

\section{Basophils}

Besides mast cells, basophils are one of the key effector cells in allergic diseases since they express the high-affinity Fce receptor and also play an important role during the Th2 skewing of the immune response $[81,82]$. Historically, the discrimination between basophils and mast cells was challenging, however, in contrast to mast cells, basophils have a much shorter half-life (days instead of weeks),

Int Arch Allergy Immunol 2016;169:1-12 DOI: $10.1159 / 000444753$ 
they circulate in peripheral blood but have also the capability to home to inflamed tissues [83]. The role of basophils during the development of Th2-driven allergic immune responses was reviewed recently [84], clearly demonstrating the importance of this cell type in allergic diseases but also as a potential target for specific therapy. In an attempt to better characterize basophils, Watson et al. [85] showed that human basophils also express the nicotinic acetylcholine receptors $\alpha_{4}, \alpha_{7}$, and also the $\alpha_{1}, \alpha_{3}, \alpha_{5}$ subunits on their surface. Moreover, they provided evidence that a synthetic nicotinic ligand, i.e. ASM-024, can inhibit basophil activation in vitro in a dose-dependent manner. Two patient groups with mild allergic asthma were treated with either 100 or $500 \mu \mathrm{M}$ of ASM- 024 on 9 consecutive days. Patients were challenged by exposure to nebulized specific allergen on day 8 and their peripheral blood basophils were assessed by determining CD203c expression levels $24 \mathrm{~h}$ later. Notably, basophils from patients in both treatment groups revealed significantly reduced basophil activation when compared to the basophils of placebo-treated patients, explaining previous findings that ASM-024 is able to reduce airway hypersensitivity. This study identifies nicotinic acetylcholine receptors as interesting targets to regulate allergen-specific basophil activation in vivo. In functional terms, a large number of studies have shown that quantification of basophil activation by flow cytometry in the basophil activation test (BAT) helps to assess IgE-driven immediate-type responses to allergens in allergic individuals [86]. Of note, both direct and indirect BAT represent highly sensitive laboratory tests to evaluate the sensitization of individuals to allergens or drugs $[87,88]$. In the case of drugs, the drug itself or respective metabolites thereof might be the culprits leading to IgE-dependent basophil activation and degranulation. Fluoroquinolones represent an important class of antibiotics, inhibiting bacterial growth by interference with DNA gyrase, however, they frequently also cause allergic reactions. Mayorga et al. [89] could show that fluoroquinolones are highly photodegradable. This circumstance poses a considerable problem when BAT is performed at standard laboratory light conditions in order to identify fluoroquinolone sensitization. Thus, the authors strongly recommend performing BAT tests evaluating fluoroquinolone sensitization strictly protected from light, especially when moxifloxacin is the suspected culprit drug.

Although distinct laboratory conditions might negatively impact on the performance of the BAT, this test is clearly superior to simple determination of allergen-specific serum IgE levels. In contrast to double-blind, placebocontrolled food challenge, it represents a nonsubjective, nonbiased test system to evaluate treatment success in patients with oral allergy syndrome. Along these lines, Inuo et al. [90] could show that subcutaneous immunotherapy with Japanese cedar pollen extracts reduced the Japanese cedar pollen-specific and tomato fruit-specific BAT, however, this was only observed in patients who did not report tomato fruit-specific symptoms such as an oral allergy symptom. While the effect on tomato-induced BAT modulation is of great interest, the fact that the few patients with tomato oral allergy syndrome included into this study did not show decreased BAT might mirror high IgE sensitization levels not controlled by blocking antibodies and certainly warrants additional studies with larger patient collectives.

\section{Eosinophils}

Eosinophilic granulocytes belong to the innate immune system and play an important role as effector cells in allergic inflammation [91, 92]. Activated eosinophils release cytotoxic molecules such as major basic protein, eosinophil peroxidase, eosinophilic cationic protein, lipid mediators and cytokines that are important in the defense against foreign pathogens but can also cause tissue damage and promote tissue remodeling [91, 92].

Especially in allergic asthma, it was shown that eosinophils are driving tissue remodeling, strongly contributing to one of the key pathologies of that disease [93]. Accordingly, Tang et al. [94] investigated IL-25 plasma levels and IL-25 receptor expression levels (IL17-RA and IL-17RB) on eosinophils derived from mild allergic asthma patients, atopic nonasthmatic patients and normal individuals. IL-25 becomes produced by epithelial cells and stimulates the production of IL-4, IL- 5 and IL- 13 by effector T cells, which, in the form of a positive feedback loop, leads to eosinophil recruitment. The authors could demonstrate that patients with allergic asthma presented with elevated IL-25 plasma levels and that the corresponding eosinophils revealed significantly higher expression levels of both IL-17A and IL$17 \mathrm{~B}$ receptors (forming the IL-25 receptor) when compared to both atopic nonasthmatic individuals and healthy controls. These results show that IL-25 plays a pivotal role in allergic asthma, provides an explanation as to why persistent increases of eosinophils are observed in these patients, and might in fact represent one of the very initial factors driving asthma.

With regard to diagnostic procedures, the presence of eosinophils in the sputum is often taken as an indicator for the classification of the asthma phenotype involved 
Table 1. Studies related to allergic asthma and key findings

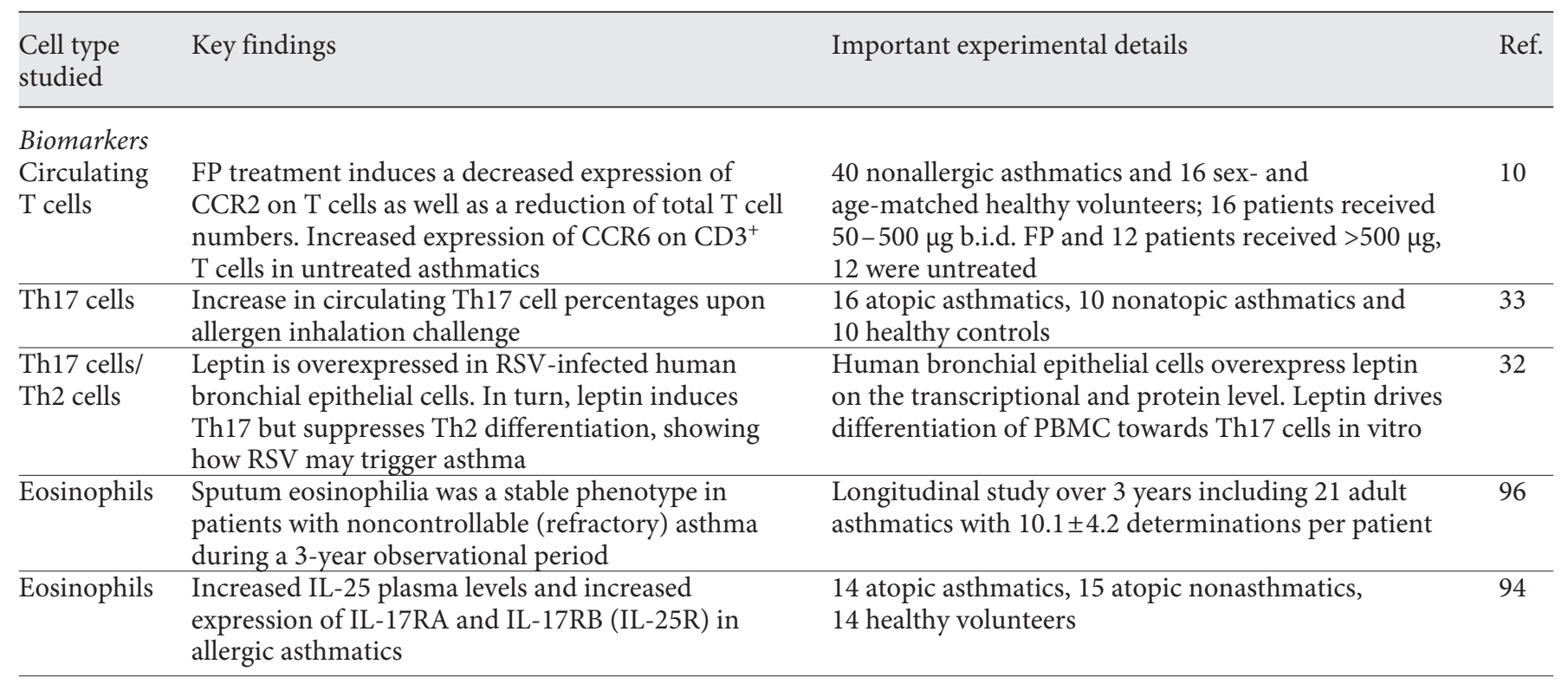

Treatment strategies and models

CD4 T cells Dietary GOS reduce IL-33 secretion (lung and BAL) in a murine model of house dust mite-induced

Balb/c mice intranasally sensitized to $1 \mu \mathrm{g}$ of house 5 asthma

Th17 cells Blocking the CCL2/CCR2 axis in murine asthma reduces Th17 recruitment and suppresses airway inflammation

Treg cells 5-Azacytidine increases Treg cells in PB and diminishes airway hyperreactivity, pulmonary eosinophilia and OVA-specific IgE titers dust mite allergen, challenged with $10 \mu \mathrm{g}$ i.n. on day 7

$\mathrm{Balb} / \mathrm{c}$ mice sensitized with $100 \mu \mathrm{g}$ of OVA and alum i.p. on days 0,7 and 14 challenged on day 24 with $200 \mu \mathrm{g}$ OVA i.t.

Balb/c mice sensitized i.p. with $50 \mu \mathrm{g}$ of OVA on days

$1,2,3$ and 14; aerosol challenge on days 14, 17, 20, 23 and 26. Injection of the drug twice weekly during sensitization

\begin{tabular}{lll}
\hline Monocytes & $\begin{array}{l}\text { Vitamin } \mathrm{D}_{3} \text { synergizes with glucocorticoids to } \\
\text { induce apoptosis of } \mathrm{CD} 14^{+} \mathrm{CD} 16^{++} \text {monocytes in } \\
\text { asthmatics }\end{array}$ & Asthma patients and healthy volunteers \\
\hline Basophils & $\begin{array}{l}\text { Basophils express nicotinic receptors, and the } \\
\text { nicotinic ligand ASM-024 decreases basophil } \\
\text { activation in allergic asthmatics }\end{array}$ & $\begin{array}{l}\text { Randomized, double-blind, placebo-controlled study. } \\
\text { Receptor expression study included } 9 \text { subjects and } 12 \\
\text { mild allergic asthmatics completed the intervention } \\
\text { study }\end{array}$ \\
\hline Th2 cells & $\begin{array}{l}\text { Subcutaneous immunotherapy in birch } \\
\text { pollen-allergic mice suppresses Th2-mediated } \\
\text { eosinophilic airway inflammation early on. }\end{array}$ & $\begin{array}{l}\text { Balb/c mice, sensitized i.p. with birch pollen extract } \\
\text { on days 0, 7 and 14 and treated for different periods } \\
\text { with birch pollen extract as subcutaneous } \\
\text { AHR becomes only reduced after induction of high }\end{array}$ \\
& $\begin{array}{l}\text { immotherapy and aerosol challenge } \\
\text { titers of allergen-specific IgG2a }\end{array}$ &
\end{tabular}

Potential new targets

Mast cells Cocultured activated mast cells induce IL-6 and IL-8 secretion by human airway smooth muscle cells

In vitro study using the HMC-1 mast cell line and 74 primary human airway smooth muscle

and to show whether or not the disease is well controlled, i.e. is lacking frequent exacerbations [95]. Dente et al. [96] performed a 3-year longitudinal study in a group of 21 patients suffering from severe refractory asthma and queried the stability of sputum eosinophilia in that patient collective. Per patient, $10.1 \pm 4.2$ sputum samples were analyzed in the observation period. Of note, in these patients sputum eosinophilia seems to be a rather constant phenotype, with $87 \%$ of the patients presenting with elevated numbers of sputum eosinophils throughout the observation period, making this simple laboratory parameter a very reliable marker. 
Allergic rhinitis has previously been shown to be responsive, among other therapeutics, to the intranasal application of steroids [97]. More recently, fluticasone furoate was shown to impact on both epithelial cell and on eosinophil survival. A novel mechanism by which steroids might impact on eosinophil survival has been characterized by Mullol et al. [98]. In fact, fluticasone furoate decreased the serum-induced production of GM-CSF, IL- 6 and IL- 8 by cultured nasal mucosa epithelial cells, which in turn led to reduced survival of enriched peripheral blood eosinophils in such conditioned media. These findings may give important new insights into the treatment options of inflammatory conditions involving the nasal epithelium in which eosinophilic infiltration is part of the problem. Thus, fluticasone furoate is not only antiinflammatory, but also decreases eosinophil survival.

\section{Summary and Conclusions}

A number of exciting studies and models on cellular allergology were reported between 2013 and 2015 (table 1). Besides the meticulous identification and validation of new biomarkers for monitoring disease activity and the success of treatment in allergy, novel and highly interesting in vitro and in vivo model systems, for example to evaluate the activity of nutritional supplements or probiotics or the efficacy of specific immunotherapy, have been established. The reports published are excellent proof of the fact that both basic and applied research activities are cornerstones with which to improve our understanding of hypersensitivity reactions and their cure.

\section{Acknowledgement}

This work was supported by the Austrian Science Fund (FWF) grants DK w1248 and SFB F4609.

\section{References}

1 Zhu J, Paul WE: Peripheral CD4+ T-cell differentiation regulated by networks of cytokines and transcription factors. Immunol Rev 2010;238:247-262.

2 Cantor H, Asofsky R: Synergy among lymphoid cells mediating the graft-versus-host response. II. Synergy in graft-versus-host reactions produced by Balb-c lymphoid cells of differing anatomic origin. J Exp Med 1970; 131:235-246.

3 Mosmann TR, Cherwinski H, Bond MW, Giedlin MA, Coffman RL: Two types of murine helper T cell clone. I. Definition according to profiles of lymphokine activities and secreted proteins. J Immunol 1986;136:23482357.

4 Jutel M, Akdis M, Budak F, Aebischer-Casaulta C, Wrzyszcz M, Blaser K, Akdis CA: IL10 and TGF- $\beta$ cooperate in the regulatory $\mathrm{T}$ cell response to mucosal allergens in normal immunity and specific immunotherapy. Eur J Immunol 2003;33:1205-1214.

5 Verheijden KA, Akbari P, Willemsen LE, Kraneveld AD, Folkerts G, Garssen J, FinkGremmels J, Braber S: Inflammation-induced expression of the alarmin interleukin $33 \mathrm{can}$ be suppressed by galacto-oligosaccharides. Int Arch Allergy Immunol 2015;167:127-136.

6 Schmitz J, Owyang A, Oldham E, Song Y, Murphy E, McClanahan TK, Zurawski G, Moshrefi M, Qin J, Li X, Gorman DM, Bazan JF, Kastelein RA: IL-33, an interleukin-1-like cytokine that signals via the IL-1 receptor-related protein ST2 and induces T helper type 2-associated cytokines. Immunity 2005;23: 479-490.
7 Holvoet S, Zuercher AW, Julien-Javaux F, Perrot M, Mercenier A: Characterization of candidate anti-allergic probiotic strains in a model of Th2-skewed human peripheral blood mononuclear cells. Int Arch Allergy Immunol 2013;161:142-154.

8 Jabara HH, Fu SM, Geha RS, Vercelli D: CD40 and IgE: synergism between anti-CD40 monoclonal antibody and interleukin 4 in the induction of IgE synthesis by highly purified human B cells. J Exp Med 1990;172:18611864.

9 DeVries ME, Kelvin AA, Xu L, Ran L, Robinson J, Kelvin DJ: Defining the origins and evolution of the chemokine/chemokine receptor system. J Immunol 2005;176:401-415.

10 Barbarroja-Escudero J, Prieto-Martin A, Monserrat-Sanz J, Reyes-Martin E, DiazMartin D, Antolin-Amerigo D, RodriguezRodriguez M, Canseco-Gonzalez F, Kremer L, Martinez AC, Alvarez-Mon M: Abnormal chemokine receptor profile on circulating $\mathrm{T}$ lymphocytes from nonallergic asthma patients. Int Arch Allergy Immunol 2014;164: 228-236.

11 Wang A, Wang Z, Cao Y, Cheng S, Chen H, Bunjhoo H, Xie J, Wang C, Xu Y, Xiong W: CCL2/CCR2-dependent recruitment of Th17 cells but not Tc17 cells to the lung in a murine asthma model. Int Arch Allergy Immunol 2015; 166:52-62.

12 Kay AB, Kaplan AP, Bousquet J, Holt PG (eds): Allergy and Allergic Diseases, ed 2. Oxford, Wiley-Blackwell, 2008.
13 Wolk K, Witte E, Witte K, Warszawska K, Sabat R: Biology of interleukin-22. Semin Immunopathol 2010;32:17-31.

14 Duhen T, Geiger R, Jarrossay D, Lanzavecchia A, Sallusto F: Production of interleukin 22 but not interleukin 17 by a subset of human skinhoming memory T cells. Nat Immunol 2009; 10:857-863.

15 Niebuhr M, Mainardy J, Heratizadeh A, Satzger I, Werfel T: Staphylococcal exotoxins induce interleukin 22 in human Th22 cells. Int Arch Allergy Immunol 2014;165:35-39.

16 Dominguez-Amorocho O, Duarte S, Gonzalez JM, Halpert E, Ortega MC, Rodriguez A, Garcia E, Cuellar A: Differences in systemic and skin migrating-specific CD4 T cells in papular urticaria by flea bite. Int Arch Allergy Immunol 2013;160:165-172.

17 Forster R, Mattis AE, Kremmer E, Wolf E, Brem G, Lipp M: A putative chemokine receptor, BLR1, directs B cell migration to defined lymphoid organs and specific anatomic compartments of the spleen. Cell 1996;87: 1037-1047.

18 Forster R, Schubel A, Breitfeld D, Kremmer E, Renner-Muller I, Wolf E, Lipp M: CCR7 coordinates the primary immune response by establishing functional microenvironments in secondary lymphoid organs. Cell 1999;99:23-33.

19 Shoji J, Nakanishi Y, Ishimori A, Sakimoto T, Inada $\mathrm{N}$, Nemoto $\mathrm{N}$ : Involvement of chemokines and a CD4-positive T cell subset in the development of conjunctival secondary lymphoid follicles in an atopic keratoconjunctivitis mouse model. Int Arch Allergy Immunol 2015;167:147-157. 
20 Valenta R, Campana R, Marth K, van Hage M: Allergen-specific immunotherapy: from therapeutic vaccines to prophylactic approaches. J Intern Med 2012;272:144-157.

21 Neunkirchner A, Schmetterer KG, Pickl WF: Lymphocyte-based model systems for allergy research: a historic overview. Int Arch Allergy Immunol 2014;163:259-291.

22 van Rijt LS, Gouveia L, Logiantara A, Canbaz D, Opstelten DJ, van der Kleij HP, van Ree R: Birch pollen immunotherapy in mice: inhibition of Th2 inflammation is not sufficient to decrease airway hyper-reactivity. Int Arch Allergy Immunol 2014;165:128-139.

23 Harrington LE, Hatton RD, Mangan PR, Turner H, Murphy TL, Murphy KM, Weaver CT: Interleukin 17-producing CD4+ effector $\mathrm{T}$ cells develop via a lineage distinct from the T helper type 1 and 2 lineages. Nat Immunol 2005;6:1123-1132.

24 Park H, Li Z, Yang XO, Chang SH, Nurieva R, Wang YH, Wang Y, Hood L, Zhu Z, Tian Q, Dong C: A distinct lineage of CD4 T cells regulates tissue inflammation by producing interleukin 17. Nat Immunol 2005;6:11331141.

25 Cosmi L, De Palma R, Santarlasci V, Maggi L, Capone M, Frosali F, Rodolico G, Querci V, Abbate G, Angeli R, Berrino L, Fambrini M, Caproni M, Tonelli F, Lazzeri E, Parronchi P, Liotta F, Maggi E, Romagnani S, Annunziato F: Human interleukin 17-producing cells originate from a CD161+CD4+ T cell precursor. J Exp Med 2008;205:1903-1916.

26 Kolls JK, Linden A: Interleukin-17 family members and inflammation. Immunity 2004; 21:467-476.

27 Kolls JK, Khader SA: The role of Th17 cytokines in primary mucosal immunity. Cytokine Growth Factor Rev 2010;21:443-448.

28 Aujla SJ, Chan YR, Zheng M, Fei M, Askew DJ, Pociask DA, Reinhart TA, McAllister F, Edeal J, Gaus K, Husain S, Kreindler JL, Dubin PJ, Pilewski JM, Myerburg MM, Mason CA, Iwakura Y, Kolls JK: IL-22 mediates mucosal host defense against Gram-negative bacterial pneumonia. Nat Med 2008;14:275281.

29 Cosmi L, Liotta F, Maggi E, Romagnani S, Annunziato F: Th17 and non-classic Th1 cells in chronic inflammatory disorders: two sides of the same coin. Int Arch Allergy Immunol 2014;164:171-177.

30 Oda N, Canelos PB, Essayan DM, Plunkett BA, Myers AC, Huang SK: Interleukin-17F induces pulmonary neutrophilia and amplifies antigen-induced allergic response. Am J Respir Crit Care Med 2005;171:12-18.

31 Qin L, Hu CP, Feng JT, Xia Q: Activation of lymphocytes induced by bronchial epithelial cells with prolonged RSV infection. PLoS One 2011;6:e27113.

32 Qin L, Tan YR, Hu CP, Liu XA, He RX: Leptin is oversecreted by respiratory syncytial virusinfected bronchial epithelial cells and regulates Th2 and Th17 cell differentiation. Int Arch Allergy Immunol 2015;167:65-71.
33 Naji N, Smith SG, Gauvreau GM, O’Byrne PM: T helper 17 cells and related cytokines after allergen inhalation challenge in allergic asthmatics. Int Arch Allergy Immunol 2014; 165:27-34.

34 Dhuban KB, d'Hennezel E, Ben-Shoshan M, McCusker C, Clarke A, Fiset P, Mazer B, Piccirillo CA: Altered T helper 17 responses in children with food allergy. Int Arch Allergy Immunol 2013;162:318-322.

35 Schmetterer KG, Neunkirchner A, Pickl WF: Naturally occurring regulatory T cells: markers, mechanisms, and manipulation. FASEB J 2012;26:2253-2276.

36 Shevach EM, DiPaolo RA, Andersson J, Zhao DM, Stephens GL, Thornton AM: The lifestyle of naturally occurring CD4+ CD25+ Foxp3+ regulatory $\mathrm{T}$ cells. Immunol Rev 2006;212:60-73.

37 Ling EM, Smith T, Nguyen XD, Pridgeon C, Dallman M, Arbery J, Carr VA, Robinson DS: Relation of $\mathrm{CD} 4+\mathrm{CD} 25+$ regulatory $\mathrm{T}$-cell suppression of allergen-driven T-cell activation to atopic status and expression of allergic disease. Lancet 2004;363:608-615.

38 Akdis M, Blaser K, Akdis CA: T regulatory cells in allergy: novel concepts in the pathogenesis, prevention, and treatment of allergic diseases. J Allergy Clin Immunol 2005;116:961-968.

39 Francis JN, Till SJ, Durham SR: Induction of IL-10+CD4+CD25+ T cells by grass pollen immunotherapy. J Allergy Clin Immunol 2003;111:1255-1261.

40 Radulovic S, Jacobson MR, Durham SR, Nouri-Aria KT: Grass pollen immunotherapy induces Foxp3-expressing CD4+ CD25+cells in the nasal mucosa. J Allergy Clin Immunol 2008;121:1467-1472.

41 Stelmaszczyk-Emmel A, Zawadzka-Krajewska A, Szypowska A, Kulus M, Demkow U: Frequency and activation of CD4+CD25 Foxp3+ regulatory $\mathrm{T}$ cells in peripheral blood from children with atopic allergy. Int Arch Allergy Immunol 2013;162:16-24.

42 Chatila TA: Role of regulatory T cells in human diseases. J Allergy Clin Immunol 2005; 116:949-959.

43 Daniel C, Wennhold K, Kim HJ, von Boehmer $\mathrm{H}$ : Enhancement of antigen-specific Treg vaccination in vivo. Proc Natl Acad Sci USA 2010;107:16246-16251.

44 Taylor A, Verhagen J, Akdis CA, Akdis M: T regulatory cells in allergy and health: a question of allergen specificity and balance. Int Arch Allergy Immunol 2004;135:73-82.

45 Wu CJ, Yang CY, Chen YH, Chen CM, Chen LC, Kuo ML: The DNA methylation inhibitor 5 -azacytidine increases regulatory $\mathrm{T}$ cells and alleviates airway inflammation in ovalbuminsensitized mice. Int Arch Allergy Immunol 2013;160:356-364.

46 Enomoto M, Noguchi S, Hattori M, Sugiyama H, Suzuki Y, Hanaoka A, Okada S, Yoshida T: Oral administration of Lactobacillus plantarum nric0380 suppresses IgE production and induces $\mathrm{CD}^{+} \mathrm{CD} 25^{+} \mathrm{Foxp}^{+}$cells in vivo. Biosci Biotechnol Biochem 2009;73:457-460.
47 Yoshida T, Fujiwara W, Enomoto M, Nakayama S, Matsuda H, Sugiyama $H$, Shimojoh $M$, Okada S, Hattori M: An increased number of CD4+CD25+ cells induced by an oral administration of Lactobacillus plantarum NRIC0380 are involved in antiallergic activity. Int Arch Allergy Immunol 2013;162:283289.

48 Jang E, Cho WS, Cho ML, Park HJ, Oh HJ, Kang SM, Paik DJ, Youn J: Foxp3+ regulatory $\mathrm{T}$ cells control humoral autoimmunity by suppressing the development of long-lived plasma cells. J Immunol 2011;186:1546-1553.

49 Gri G, Piconese S, Frossi B, Manfroi V, Merluzzi S, Tripodo C, Viola A, Odom S, Rivera J, Colombo MP, Pucillo CE: CD4+CD25+ regulatory $\mathrm{T}$ cells suppress mast cell degranulation and allergic responses through OX40-OX40L interaction. Immunity 2008;29:771-781.

50 Srinoulprasert Y, Pichler WJ: Enhancement of drug-specific lymphocyte proliferation using $\mathrm{CD} 25^{\text {hi }}$-depleted $\mathrm{CD}^{+}$effector cells. Int Arch Allergy Immunol 2014;163:198-205.

51 Steinman RM, Cohn ZA: Identification of a novel cell type in peripheral lymphoid organs of mice. I. Morphology, quantitation, tissue distribution. J Exp Med 1973;137: 1142-1162.

52 Ruiter B, Shreffler WG: The role of dendritic cells in food allergy. J Allergy Clin Immunol 2012;129:921-928.

53 Zhou LJ, Tedder TF: CD14+ blood monocytes can differentiate into functionally mature CD83+ dendritic cells. Proc Natl Acad Sci USA 1996;93:2588-2592.

54 Pickl WF, Majdic O, Kohl P, Stockl J, Riedl E, Scheinecker C, Bello-Fernandez C, Knapp W: Molecular and functional characteristics of dendritic cells generated from highly purified CD14+ peripheral blood monocytes. J Immunol 1996;157:3850-3859.

55 Froidure A, Shen C, Gras D, van Snick J, Chanez P, Pilette C: Myeloid dendritic cells are primed in allergic asthma for thymic stromal lymphopoietin-mediated induction of Th2 and Th9 responses. Allergy 2014;69: 1068-1076.

56 Ashjaei K, Bublin M, Smole U, Lengger N, Hafner C, Breiteneder H, Wagner S, Hoffmann-Sommergruber K: Differential T-helper cell polarization after allergen-specific stimulation of autologous dendritic cells in polysensitized allergic patients. Int Arch Allergy Immunol 2015;166:97-106.

57 Dong M, Wang X, Liu J, Zhao YX, Chen XL Li KQ, Li G: Rapamycin combined with immature dendritic cells attenuates obliterative bronchiolitis in trachea allograft rats by regulating the balance of regulatory and effector $\mathrm{T}$ cells. Int Arch Allergy Immunol 2015;167: 177-185.

58 Matzinger P: Tolerance, danger, and the extended family. Annu Rev Immunol 1994;12: 991-1045.

59 Jutel M, Watanabe T, Akdis M, Blaser K, Akdis CA: Immune regulation by histamine. Curr Opin Immunol 2002;14:735-740. 
60 Glatzer F, Mommert S, Kother B, Gschwandtner M, Stark H, Werfel T, Gutzmer R: Histamine downregulates the Th1-associated chemokine IP-10 in monocytes and myeloid dendritic cells. Int Arch Allergy Immunol 2014; 163:11-19.

61 Lee CL, Hsu SH, Jong YJ, Hung CH, Suen JL: Inhibition of histamine $\mathrm{H} 1$ receptor activity modulates proinflammatory cytokine production of dendritic cells through c-Rel activity. Int Arch Allergy Immunol 2013;160:265274.

62 Hrusch CL, Tjota MY, Sperling AI: The role of dendritic cells and monocytes in the maintenance and loss of respiratory tolerance. Curr Allergy Asthma Rep 2015; 15:494.

63 Wong KL, Yeap WH, Tai JJ, Ong SM, Dang TM, Wong SC: The three human monocyte subsets: implications for health and disease. Immunol Res 2012;53:41-57.

64 Ziegler-Heitbrock L: The CD14+CD16+ blood monocytes: their role in infection and inflammation. J Leukoc Biol 2007;81:584592.

65 Moniuszko M, Bodzenta-Lukaszyk A, Kowal K, Lenczewska D, Dabrowska M: Enhanced frequencies of CD14++CD16+, but not CD14+CD16+, peripheral blood monocytes in severe asthmatic patients. Clin Immunol 2009;130:338-346.

66 Grubczak K, Lipinska D, Eljaszewicz A, Singh P, Radzikowska U, Miklasz P, Dabrowska M, Jablonska E, Bodzenta-Lukaszyk A, Moniuszko M: Vitamin $\mathrm{D}_{3}$ treatment decreases frequencies of CD16-positive and TNF- $\alpha$ secreting monocytes in asthmatic patients. Int Arch Allergy Immunol 2015;166:170-176.

67 Marshall JS: Mast-cell responses to pathogens. Nat Rev Immunol 2004;4:787-799.

68 Janssens AS, Heide R, den Hollander JC, Mulder PG, Tank B, Oranje AP: Mast cell distribution in normal adult skin. J Clin Pathol 2005;58:285-289.

69 Galli SJ, Tsai M, Piliponsky AM: The development of allergic inflammation. Nature 2008; 454:445-454.

70 Butterfield JH, Weiler D, Dewald G, Gleich GJ: Establishment of an immature mast cell line from a patient with mast cell leukemia. Leuk Res 1988;12:345-355.

71 Kirshenbaum AS, Akin C, Wu YL, Rottem M, Goff JP, Beaven MA, Rao VK, Metcalfe DD: Characterization of novel stem cell factor responsive human mast cell lines LAD 1 and 2 established from a patient with mast cell sarcoma/leukemia; activation aggregation of FceRI or Fc $\gamma$ RI. Leuk Res 2003;27:677-682.

72 Laidlaw TM, Steinke JW, Tinana AM, Feng CL, Xing W, Lam BK, Paruchuri S, Boyce JA, Borish L: Characterization of a novel human mast cell line that responds to stem cell factor and expresses functional FceRI. J Allergy Clin Immunol 2011;127:815-822.
73 Kirshenbaum AS, Petrik A, Walsh R, Kirby TL, Vepa S, Wangsa D, Ried T, Metcalfe DD: A ten-year retrospective analysis of the distribution, use and phenotypic characteristics of the LAD2 human mast cell line. Int Arch Allergy Immunol 2014;164:265-270.

74 Xia YC, Harris T, Stewart AG, Mackay GA: Secreted factors from human mast cells trigger inflammatory cytokine production by human airway smooth muscle cells. Int Arch Allergy Immunol 2013;160:75-85.

75 Weller CL, Collington SJ, Hartnell A, Conroy DM, Kaise T, Barker JE, Wilson MS, Taylor GW, Jose PJ, Williams TJ: Chemotactic action of prostaglandin E2 on mouse mast cells acting via the PGE2 receptor 3. Proc Natl Acad Sci USA 2007;104:11712-11717.

76 Collington SJ, Hallgren J, Pease JE, Jones TG, Rollins BJ, Westwick J, Austen KF, Williams TJ, Gurish MF, Weller CL: The role of the CCL2/CCR2 axis in mouse mast cell migration in vitro and in vivo. J Immunol 2010;184: 6114-6123.

77 Noma N, Asagiri M, Takeiri M, Ohmae S, Takemoto K, Iwaisako K, Minato N, MaedaYamamoto M, Simizu S, Umezawa K: Inhibition of MMP-2-mediated mast cell invasion by NF- $\kappa B$ inhibitor DHMEQ in mast cells. Int Arch Allergy Immunol 2015;166:84-90.

78 Rönnberg E, Calounova G, Sutton VR, Trapani JA, Rollman O, Hagforsen E, Pejler G: Granzyme $\mathrm{H}$ is a novel protease expressed by human mast cells. Int Arch Allergy Immunol 2014;165:68-74.

79 Hagel AF, deRossi T, Zopf Y, Konturek P, Dauth W, Kressel J, Hahn EG, Raithel M: Mast cell tryptase levels in gut mucosa in patients with gastrointestinal symptoms caused by food allergy. Int Arch Allergy Immunol 2013;160:350-355.

80 Cifuentes L, Ring J, Brockow K: Clonal mast cell activation syndrome with anaphylaxis to sulfites. Int Arch Allergy Immunol 2013;162: 94-96.

81 Knol EF, Olszewski M: Basophils and mast cells: underdog in immune regulation? Immunol Lett 2011;138:28-31.

82 Crivellato E, Nico B, Ribatti D: The history of the controversial relationship between mast cells and basophils. Immunol Lett 2011;141: 10-17.

83 Karasuyama H, Mukai K, Obata K, Tsujimura Y, Wada T: Nonredundant roles of basophils in immunity. Annu Rev Immunol 2011;29: 45-69.

84 van Beek AA, Knol EF, de Vos P, Smelt MJ, Savelkoul HF, van Neerven RJ: Recent developments in basophil research: do basophils initiate and perpetuate type $2 \mathrm{~T}$-helper cell responses? Int Arch Allergy Immunol 2013;160: $7-17$

85 Watson BM, Oliveria JP, Nusca GM, Smith SG, Beaudin S, Dua B, Watson RM, Assayag EI, Cormier YF, Sehmi R, Gauvreau GM: Inhibition of allergen-induced basophil activation by ASM-024, a nicotinic receptor ligand. Int Arch Allergy Immunol 2014;165:255-264.
86 Chirumbolo S: Basophil activation test in allergy: time for an update? Int Arch Allergy Immunol 2012;158:99-114.

87 Erdmann SM, Heussen N, Moll-Slodowy S, Merk HF, Sachs B: CD63 expression on basophils as a tool for the diagnosis of pollen-associated food allergy: sensitivity and specificity. Clin Exp Allergy 2003;33:607-614.

88 Moneret-Vautrin DA, Sainte-Laudy J, Kanny G, Fremont S: Human basophil activation measured by CD63 expression and LTC4 release in IgE-mediated food allergy. Ann Allergy Asthma Immunol 1999;82:33-40.

89 Mayorga C, Andreu I, Aranda A, Dona I, Montanez MI, Blanca-Lopez N, Ariza A, Nuin E, Blanca M, Miranda MA, Torres MJ: Fluoroquinolone photodegradation influences specific basophil activation. Int Arch Allergy Immunol 2013;160:377-382.

90 Inuo C, Kondo Y, Tanaka K, Nakajima Y, Nomura T, Ando H, Suzuki S, Tsuge I, Yoshikawa T, Urisu A: Japanese cedar pollen-based subcutaneous immunotherapy decreases tomato fruit-specific basophil activation. Int Arch Allergy Immunol 2015;167:137-145.

91 Gangwar RS, Friedman S, Seaf M, Levi-Schaffer F: Mast cells and eosinophils in allergy: close friends or just neighbors. Eur J Pharmacol 2015, Epub ahead of print.

92 Hogan SP, Rosenberg HF, Moqbel R, Phipps S, Foster PS, Lacy P, Kay AB, Rothenberg ME: Eosinophils: biological properties and role in health and disease. Clin Exp Allergy 2008;38: 709-750.

93 Humbles AA, Lloyd CM, McMillan SJ, Friend DS, Xanthou G, McKenna EE, Ghiran S, Gerard NP, Yu CN, Orkin SH, Gerard C: A critical role for eosinophils in allergic airways remodeling. Science 2004;305:1776-1779.

94 Tang W, Smith SG, Beaudin S, Dua B, Howie K, Gauvreau G, O'Byrne PM: IL-25 and IL-25 receptor expression on eosinophils from subjects with allergic asthma. Int Arch Allergy Immunol 2014;163:5-10.

95 Simpson JL, Scott R, Boyle MJ, Gibson PG: Inflammatory subtypes in asthma: assessment and identification using induced sputum. Respirology 2006;11:54-61.

96 Dente FL, Latorre M, Novelli F, Cianchetti S, Bartoli ML, Bacci E, Di Franco A, Vagaggini B, Celi A, Paggiaro P: Can sputum eosinophilia be a constant feature in severe refractory asthmatics? A 3-year longitudinal study. Int Arch Allergy Immunol 2015;166:287-290.

97 Berman BA: Allergic rhinitis - mechanisms and management. J Allergy Clin Immunol 1988;81:980-984.

98 Mullol J, Pujols L, Alobid I, Perez-Gonzalez M, Fuentes M, de Borja Callejas F, Valero A, Picado C, Roca-Ferrer J: Fluticasone furoate inhibits cytokine secretion from nasal epithelial cells and reduces eosinophil survival in an in vitro model of eosinophilic inflammation. Int Arch Allergy Immunol 2014;163:225-233. 